\title{
REQUALIFICAÇÃO DO CENTRO ANTIGO DE SALVADOR ATRAVÉS DE INSTRUMENTOS DO ESTATUTO DA CIDADE
}

\author{
Silvia Carreira de Meneses Andrade \\ Faculdade Ruy Barbosa DeVry Brasil \\ scar@atarde.com.br \\ Liliane Ferreira Mariano da Silva \\ Universidade do Estado da Bahia \\ liliane@lognet.com.br \\ João Soares Pena \\ Faculdade Ruy Barbosa DeVry Brasil \\ joaopena.88@gmail.com
}

\section{RESUMO}

Até 1970, a região econômico-financeira situada no Centro Antigo da Cidade de Salvador apresentava uma estrutura que se revelava por um dinamismo e paisagem apropriados às funções a ela destinadas, desde sua fundação. Naquele decênio, a organização urbana da área do Comércio experimentou um previsível colapso territorial, resultando na criação de uma nova centralidade urbana, mais adequada às mudanças estruturais da economia nacional. Tal iniciativa levou a transformações endêmicas e dilapidação da identidade urbana e patrimonial da região, expressa na organicidade de suas funções - econômicas, sociais, culturais, históricas e arquitetônicas. Desde então têm-se elaborado diagnósticos, prognósticos e planos urbanísticos para a reabilitação do Centro Antigo, que não resolvem o esgarçamento do tecido social e o arruinamento de um patrimônio histórico e arquitetônico tão caro à cidade. Este artigo analisa a possibilidade de recuperação do Centro Antigo de Salvador na região do Comércio através de instrumentos do Estatuto da Cidade.

Palavras chave: Patrimônio. Arquitetura. Reabilitação urbana.

\begin{abstract}
Until 1970, the financial region located in the old downtown of Salvador presented a structure that was revealed by a dynamism and landscape appropriate to the functions that it had destined since its foundation. In that decade, the urban organization of the Comércio area experienced a predictable territorial collapse, resulting in the creation of an new urban centrality, more adequate to the structural changes of the national economy. This initiative led to endemic transformations and dilapidation of the urban and patrimonial identity of the region, expressed in the organicity of its functions - economic, social, cultural, historical and architectural. Since then, diagnoses, prognoses and urban plains have been developed for the rehabilitation of the old downtown, which do not solve and the ruin of a historical and architectural patrimony so dear to the city. This article analyzes the possibility of recovery of the old downtown of Salvador through instruments of the City Statute.
\end{abstract}

Keywords: Patrimony. Architecture. Urbain rehabilitation. 


\section{INTRODUÇÃO}

O crescimento das cidades decorrente da industrialização causou profundas alterações nos espaços urbanos e nas sociedades em curto espaço de tempo. No Brasil, o período da industrialização caracterizado pela forte concentração de capital em território urbano ocorreu a partir de 1950, quando surgem os polos industriais nas principais cidades do país levando ao esvaziamento do campo e crescimento demográfico, principalmente das cidades das industriais. No início do século XX, o Brasil contava com $20 \%$ da população habitando nas cidades; ao final, detinha uma população superior a $80 \%$, demandando esforços e ações não alcançadas pelos poderes públicos para garantir a qualidade de vida urbana. Os conceitos utilizados para elaboração de planos de desenvolvimento priorizavam os setores modernos da economia, a concentração do capital, particularmente do capital imobiliário, trazendo sérios problemas e desacertos para a realidade urbana.

Em Salvador, primeira cidade fundada na colônia portuguesa, o Centro Antigo apresenta sucessivas marcas da sua história, pelo conjunto de riquezas materiais e imateriais que retratam, através do seu patrimônio, o processo de desenvolvimento urbano.

O Comércio, bairro importante na formação do Centro Antigo de Salvador, está revestido de símbolos imagéticos (físicos, memoriais, relacionais, visuais) de lugar que nem mesmo o atual estado de degradação diminui a importância nos mais diversos aspectos: social, econômico, arquitetônico e urbanístico. Desde o século passado, planos, programas e projetos vêm sendo elaborados pelos poderes municipal, estadual e federal visando o desenvolvimento regional urbano. Entretanto não se observa a criação de mecanismos e instrumentos capazes de manter e/ou revitalizar a área. Ao longo do tempo, as iniciativas públicas e privadas não consideraram a complexidade desse acervo material e imaterial, gerando um processo de gentrificação e um e contínuo e perverso contexto de degradação físico ambiental e social.

O artigo ora apresentado tem como propósito demonstrar como as medidas governamentais, particularmente as legislações urbanísticas, não se debruçam nas particularidades socioambientais e econômicas do centro Antigo de Salvador, integrando-o aos propósitos do desenvolvimento urbano regional almejado para a cidade: o Centro Antigo compõe a cidade como um patrimônio cultural arquitetônico e urbanístico com potencial para o desenvolvimento do turismo local, nacional e internacional, portando deve-se articular a sua dinâmica às políticas de desenvolvimento urbano, considerando-o como uma parcela do território cujos habitantes guardam suas peculiaridades e contribuem agregando valor cultural à cidade.

Serão abordados os principais planos, projetos urbanos e legislações urbanísticas, no que diz respeito àquela área (que contribuíram para a realidade atual), até a criação do Estatuto da Cidade em 2001, Lei Federal que estabelece o cumprimento da função social do solo urbano, entre outros.

Entendemos que através da adoção dos princípios do Estatuto da Cidade possa haver a garantia da função social, integrando a legislações voltadas à preservação do acervo arquitetônico e urbanístico. Neste sentido, como metodologia utilizaram-se procedimentos exploratório, histórico e comparativo através de técnicas bibliográficas e documentais. Apresenta-se a importância do Centro Antigo desde sua formação, contextualizando-o no processo de planejamento e desenvolvimento urbano regional e finalmente explanando como a aplicação dos instrumentos do Estatuto da Cidade torna possível a integração da área do Comércio à dinâmica de um crescimento urbano democrático, inclusivo e sustentável. Ainda, como referência para tais afirmativas, incluem-se exemplos exitosos de áreas com características similares como Medellín - Colômbia e Montreal - província de Quebec, para demonstrar que é possível recuperar essa área importante para a cidade de modo menos excludente e mais socialmente justo.

\section{O DIREITO À CIDADE NO BRASIL}

O conceito do Direito à Cidade, formulado na década de 1960 pelo sociólogo francês Henry Lefebvre, traz reflexões acerca do urbanismo positivista e tecnocrático que se vinha fazendo, tendo por novidade um modelo de planejamento urbano que implicava na construção de novos bairros, abertura de vias e adensamento habitacional, destituindo de identidade os locais tradicionais das cidades, alterando e desintegrando o convívio social.

O Direito à Cidade seria o "derecho a la vida urbana, transformada, renovada. (...). Ello supone una teoria integral de la ciudad y la sociedade urbana que utilice los recursos de la ciência y arte". (LEFEBVRE, 1978). Portanto, refere-se à cidade que se dinamiza através da articulação da ciência com a arte, do espaço com o 
tempo, com o suporte social da classe operária (a população). Para tanto, Lefebvre propõe duas linhas de ação que se complementam pela implementação de programa político de reforma urbana (de base políticocientífica) com a modelagem urbana (com base criativa da apropriação).

Tais pressupostos ganharam proporções internacionais quando analisados à luz das dinâmicas reprodutivas do capitalismo, indutoras da formação de lócus de troca de produção excedente - daí surgindo o espaço urbano como canal de absorção do capital excedente. (HARVEY, 2012). Essas ideias difundiram-se e constituem uma agenda importante para as questões urbanas, inclusive no Brasil, onde ocorreu no final do século XX um forte movimento chamado de Reforma Urbana que reivindicava mudanças na produção do espaço urbano pautadas no ideário do direito à cidade, que resultaria décadas depois na regulamentação de diretrizes para a política urbana no país.

Após 20 anos de ditadura militar (1964-1984), a redação da nova Constituição Federal (CF 1988) promulgada em 1988 incorporou um sobre a política urbana nos artigos 182 e 183. É quando o país passa a ter um marco constitucional acerca do desenvolvimento urbano. Contudo, essa etapa demandava detalhamentos e a regulamentação de um conjunto instrumentos que fortalecessem as reformas estruturais necessárias à redução das desigualdades sociais urbanas, acentuadas no período totalitário. Esta regulamentação somente aconteceu após mais de 10 anos de tramitação no Congresso e muita pressão de movimentos sociais com a aprovação da Lei Federal oㅜ 10.257/2001 - a Lei do Estatuto da Cidade.

O Estatuto da Cidade resultou de um processo longo e intenso de luta social iniciado em 1963 pelo Congresso Nacional, encabeçado pelo Instituto de Arquitetos do Brasil (IAB), a Igreja Católica e diversas entidades, num momento em que segmentos progressistas da sociedade brasileira demandavam reformas estruturais na questão fundiária, sobretudo para a realização de uma reforma agrária - que não aconteceu devido ao golpe militar de 1964.

Sufocado pelo regime autoritário, o Movimento Nacional de Reforma Urbana retomou forças nos anos 1980, do qual participaram entidades profissionais de classe, sindicatos, movimentos sociais e outros. No intervalo de 20 anos, o país apresentou uma significativa inversão demográfica que refletiu nos territórios urbanos marcados por uma expansão acelerada e exacerbadas desigualdades sociais e econômicas. De população predominantemente rural nos anos 1960, o país torna-se predominantemente urbano a partir de 1970, devido à polarização migratória das indústrias situadas no entorno das cidades.

O movimento condenava a cidade enquanto fonte das desigualdades sociais que se expandiram no período ditatorial. Estava pautado em três princípios básicos: o direito à cidade e à cidadania, a gestão democrática da cidade e a função social da cidade e da propriedade. O que se buscava era um caminho que possibilitasse uma nova forma de produção do espaço urbano mais socialmente justa e equitativa, ou seja, que aos cidadãos coubesse o acesso à terra urbanizada, dispondo igualitariamente dos benefícios que ela proporciona, sobretudo às classes menos favorecidas.

Ainda que o processo das demandas iniciais por reformas urbanas tenha sido longo o bastante para a degradação das metrópoles brasileiras, a aprovação do Estatuto da Cidade representa um avanço sem precedentes na condução da política urbana, uma vez que define diretrizes para o planejamento e a gestão das cidades, com a aplicação de instrumentos fundamentais à efetivação e operacionalização das urgentes reformas urbanas que garantam aos cidadãos o Direito à Cidade.

Nessa perspectiva, os princípios contidos no Estatuto da Cidade possibilitam aos municípios o exercício do direito à cidade, uma vez que os instrumentos, quando regulamentados localmente, são capazes de conter a expansão indiscriminada do tecido urbano e a especulação imobiliária, além de dirimir as desigualdades socioespaciais, fomentar a produção de habitação de interesse social e proteger as comunidades consolidadas. Nesse sentido, desde 2001 tornou-se obrigatória a elaboração de planos diretores de desenvolvimento urbano (PDDU) participativos que incorporem os dispositivos do Estatuto conforme as especificidades e demandas locais. A lei federal dispõe de mecanismos de gestão pública que garantam a qualidade de vida das populações, regulamentando o uso e a ocupação do solo urbano, a preservação ambiental e os direitos e deveres dos cidadãos, para que o direito à cidade lhes seja assegurado com justiça social.

O bojo do Estatuto da Cidade abriga quatro eixos que incorporam instrumentos de regulação, com a possibilidade de aplicação paulatina e/ou sucessória. Devem constar no PDDU para que as diretrizes nele expressas sejam efetivadas. Eles estão direcionados à preservação de bens patrimoniais (construídos, 
históricos, naturais e outros), inserção social e desenvolvimento econômico, acesso aos serviços urbanos pela população, à regularização fundiária e urbanística da população mais carente através de um sistema de gestão pública justo e ágil nas ações e resultados.

São eles:

- Instrumentos de gestão democrática: têm por fundamento a participação dos cidadãos nos processos decisórios relativos à política urbana (audiências públicas, fóruns, plebiscitos, referendos, obrigatoriedade de implementação do orçamento participativo, iniciativas populares, conferências de cidades, e outros); integração dos instrumentos de planejamento e de gestão e controle social;

- Instrumentos tributários: dispõem sobre a gestão de recursos como impostos, taxas, desapropriações, incentivos e benefícios fiscais e financeiros que venham a promover a sustentabilidade urbana que o Estatuto enseja;

- Instrumentos urbanísticos: têm por objetivo a equidade social na utilização do solo urbano;

- Instrumentos de regularização fundiária: asseguram a segurança jurídica dos assentamentos informais consolidados.

No que diz respeito à preservação e conservação do patrimônio construído, natural, social, cultural, bens materiais e imateriais, à produção habitacional e inserção social, diversos instrumentos devem estar previstos nos planos diretores municipais e implementados pelos gestores e sociedade em sentido amplo.

\section{CONSIDERAÇÕES SOBRE O PLANEJAMENTO DA CIDADE DE SALVADOR}

O Urbanismo Moderno na Bahia é marcado pela I Semana de Urbanismo de Salvador, em 1935, com a entrada do capitalismo industrial moderno na Bahia, fomentado por uma política desenvolvimentista. A Semana de 35 simboliza o Urbanismo sanitarista e estético-viário, com conceitos de organização, entre vários outros, da cidade, fundamentados nas tendências da época consolidadas no Congresso Internacional de Arquitetura Moderna (CIAM). A partir de então, surgem estudos e planos como o do Escritório do Plano de Urbanismo da Cidade de Salvador (EPUCS), em 1943, que enfocava prioritariamente questões viárias e sanitárias.

Na década de 1970 foi elaborado o Plano de Desenvolvimento Urbano (PLANDURB), desenvolvido num contexto de crescimento econômico acelerado, tanto em nível nacional como em nível estadual. O Plano Diretor de Desenvolvimento Urbano (PDDU) de 1985, aprovado após a regulamentação da Lei de Ordenamento do Uso e Ocupação do Solo (LOUOS), dá continuidade às propostas do PLANDURB assegurando as estratégias de desenvolvimento urbano regional nos seus aspectos econômicos. Atualmente, apesar da obrigatoriedade definida pelo Estatuto da Cidade da atualização do PDDU a cada 10 anos, uma série de estudos e planos foram desenvolvidos para a cidade, dos quais alguns foram severamente criticados ou por questões de ordens legais não foram implantados.

Mais recentemente a Prefeitura de Salvador lançou em 2014 o Plano Salvador 500, que vem a ser um conjunto de planos e projetos a serem a implementar para o desenvolvimento da cidade em 35 anos, até 2049, quando a cidade completará 500 anos. O plano foi concebido a partir da definição de estratégias de longo prazo e de ordenamento do território "sendo um insumo e produto do planejamento do desenvolvimento do município nas dimensões físico-territorial, ambiental, econômica e cultural” (SALVADOR, 2014).

O Salvador 500 foi elaborado em cinco etapas: Planejamento, Estudos Básicos, Estudos Analíticos, Estratégia de Desenvolvimento e Política Urbana. Esta última estabelece as diretrizes gerais da política urbana e os instrumentos da política urbana, previstos no Estatuto da Cidade, para um horizonte temporal de até dez anos, e compreende a elaboração dos dois principais instrumentos normativos do desenvolvimento urbano no âmbito municipal: o Plano Diretor de Desenvolvimento Urbano e a Lei de Ordenamento do Uso e Ocupação do Solo.

O atual PDDU (Lei n 9069/2016), apesar de não contrariar as diretrizes do Estatuto da Cidade, não adota novos paradigmas para um planejamento e gestão urbanos que venham indicar soluções inovadoras, particularmente para áreas como o Centro Antigo de Salvador. No artigo 139, deixa clara a necessidade de fortalecimento dessa área e da revitalização dos bairros tradicionais com a recuperação e valorização da qualidade ambiental e urbanística, a preservação do patrimônio histórico, cultural e humano, o readensamento 
populacional com diversidade social, maior oferta de usos institucionais públicos e privados e fomento à cultura, à economia criativa e ao turismo. Porém, o que se percebe é a valorização do capital imobiliário, relegando a segundo plano os aspectos socioambientais.

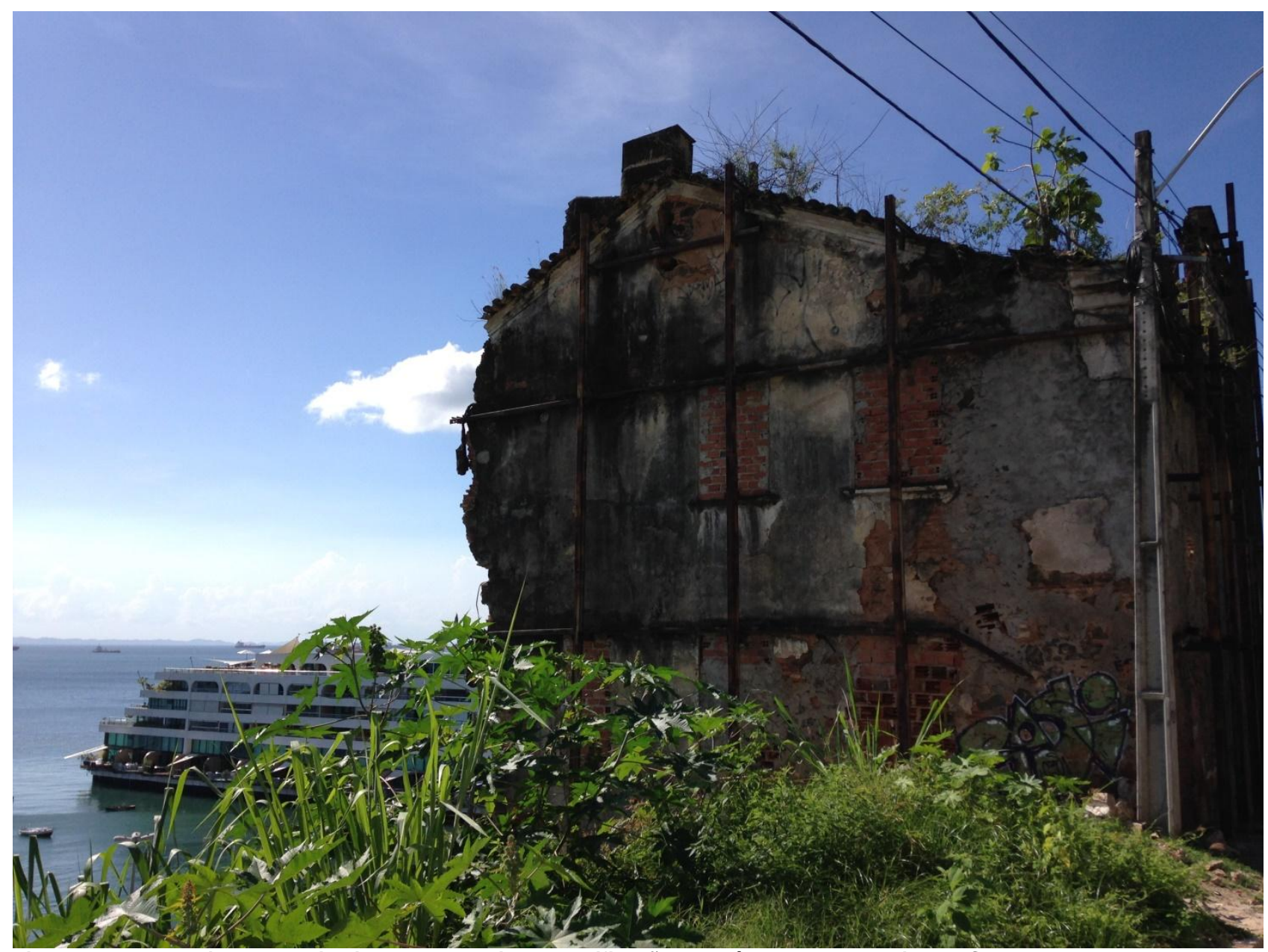

Figura 1: Empreendimento habitacional de luxo visto de edificação em ruína no centro antigo de Salvador (Carreira, 2017)

Neste contexto, apesar do Centro Antigo de Salvador e a região do Comércio serem vistos como um potencial turístico de desenvolvimento econômico, pode-se perceber um enfoque explícito em defesa dos interesses privados, empresariais, e não o interesse público, coletivo; contrários aos objetivos traçados pelo Estatuto da Cidade. Estas estratégias de reordenamento do território seguem a mesma vertente do modismo desenvolvido por Barcelona e modelado nas cidades a partir de seus check lists identitários, quando as realidades são distintas, particularmente em aspectos sócio-culturais e econômicos da população local.

\section{BREVE HISTÓRICO DA CIDADE}

Fundada em 1549, Salvador foi a primeira capital do Brasil colonial. Apêndice continental, peninsular, o sítio foi escolhido devido à localização e geografia - estratégicas - para assegurar as funções políticoadministrativas, institucionais, religiosas, habitacionais, e também comerciais e portuárias, essenciais ao processo colonizador e assentadas em duas partes do território.

A configuração urbana original de Salvador é própria das morfologias vernáculas das cidades portuguesas marítimas do século XV: dividida por uma falésia em duas zonas - a "cidade alta" e a "cidade baixa" - a organização do território tiraria proveito dessa falha geológica, em que as funções político-administrativas seriam exercidas na parte alta da cidade, enquanto as relações comerciais e atividades portuárias se estabeleceram na Cidade Baixa, às margens da Baía de Todos os Santos (BTS), - a maior do Brasil. Na Cidade Alta, situada 30 metros acima da linha d'água da Baía, a nucleação detinha as funções administrativas, religiosas e de moradia da população, assentada em um planalto e debruçada sobre a Cidade Baixa, onde 
se desenvolveram as atividades portuárias e mercantis com o ancoradouro, edifícios, habitações de padrão inferior e equipamentos de suporte ao comércio além-mar. (TEIXEIRA, 2012).

Nos primeiros dois séculos da colonização portuguesa no Brasil, Salvador deteve o maior porto do Hemisfério Sul. Conhecido como Porto do Brasil, sua localização estratégica foi de grande importância nas relações com a metrópole e países em rota com a Ásia e África.

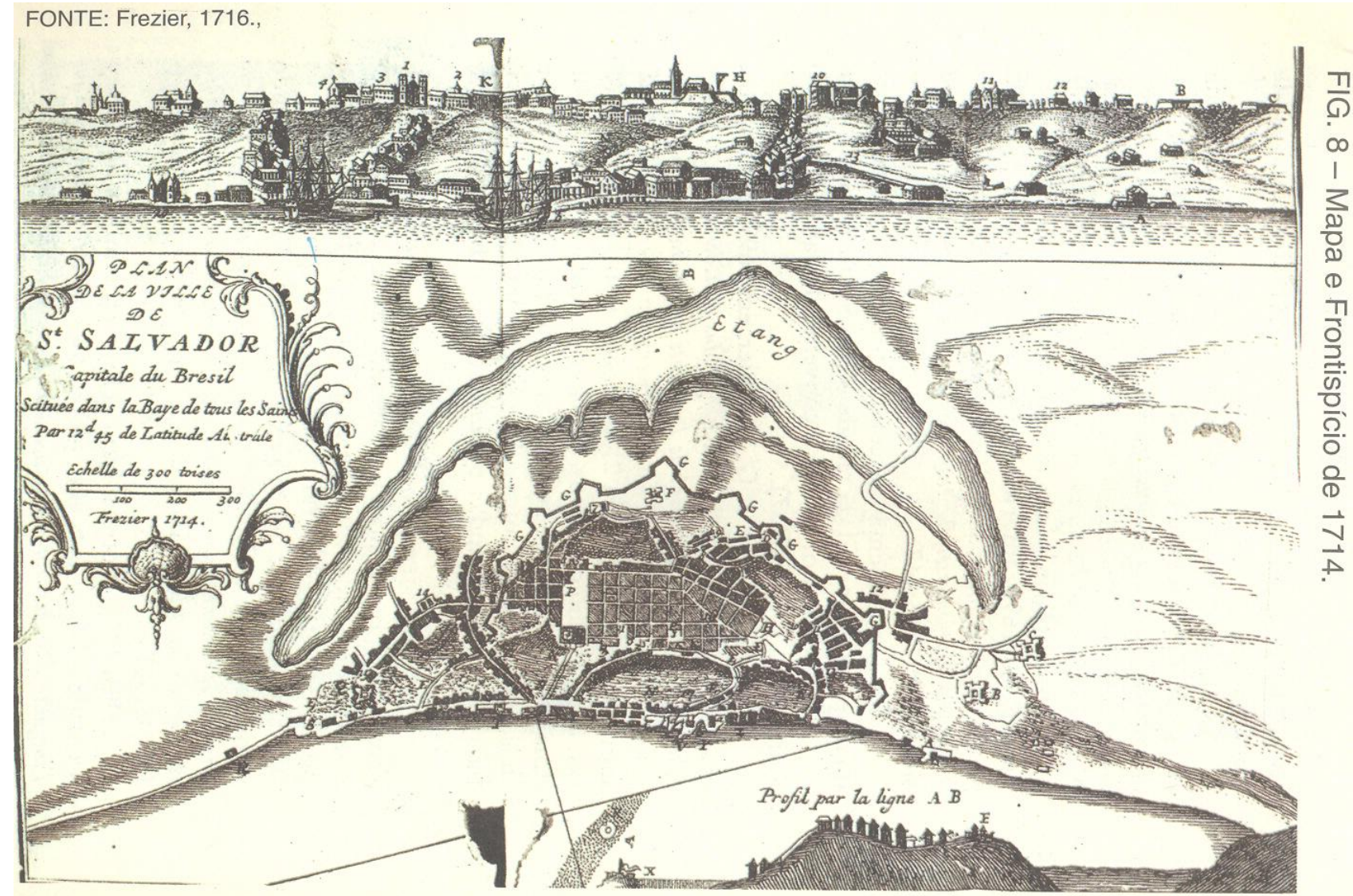

Figura 2: Planta e frontispício de Salvador em 1714

(Vasconcelos, 2002)

A exploração de ouro e diamantes, notadamente em Minas Gerais, levou à transferência da sede colonial para o Rio de Janeiro, em 1763. Até o final do século XIX, o porto de Salvador manteve suas atividades sustentadas principalmente por uma economia agroexportadora, cedendo importância ao Centro-Sul do País.

O positivismo industrial que se instalou no país no início do Século XX provocou significativas transformações nas cidades - pela expansão urbana e demográfica, por exemplo - sendo imperiosa a execução de obras que atendessem a demandas trazidas pelo capitalismo modernizador inglês. É quando as partes alta e baixa de Salvador consolidam suas identidades zonais, expandindo e dialogando funções, no território em nível de complexidade jamais verificado desde sua fundação.

Ao final do Século XIX, a ocupação da Cidade Baixa espraiava-se linearmente pela borda da Baía de Todos os Santos, a noroeste. Em 1900, a força da zona portuária original foi substituída por um centro econômico financeiro de base industrial emergente: a região passa então a ser reconhecida e nominada de Comércio ampliada e consolidada no território a partir do aterramento das águas rasas da baía, em trecho de $1 \mathrm{~km}$ a partir da linha d'água da falésia. 


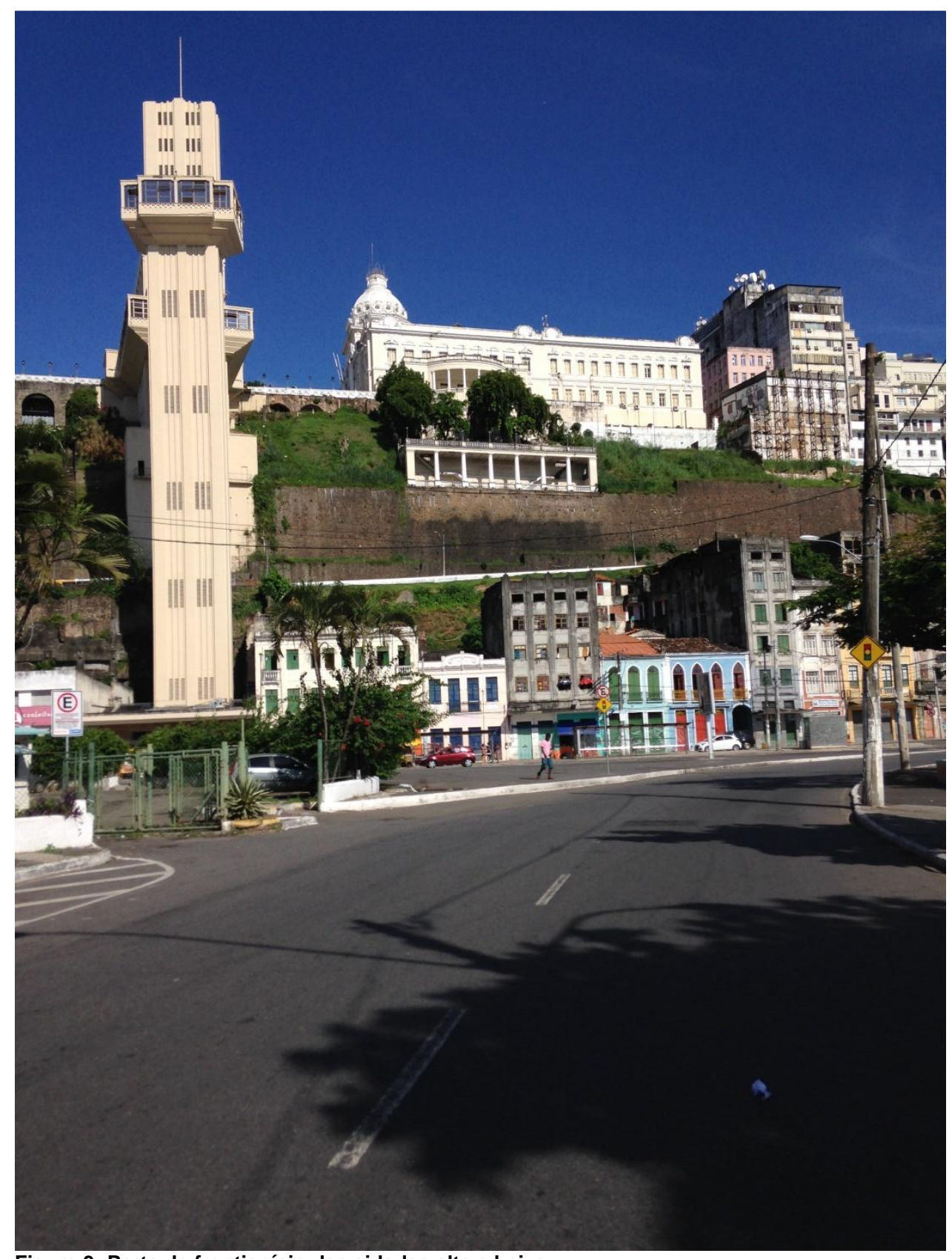

Figura 3: Parte de frontispício das cidades alta e baixa (Carreira, 2017)

De difícil acesso, a estreita região compreendida entre o Porto e a Península de Itapagipe exigia que se implantassem estruturas urbanas fundamentais à expansão da cidade, em intervenções coexistentes e compartilhadas com a Cidade Alta: enquanto acima a cidade expandia com bairros residenciais e transpunha barreiras de relevo, a zona portuária ampliava-se em novas funções e espaços, com aterramentos que possibilitaram o aquecimento das atividades comerciais e o surgimento das primeiras indústrias e novos modais de transportes.

As obras de engenharia que se realizaram nas décadas de transição entre os séculos XIX e XX, nas duas "cidades", conectavam-nas basicamente por ladeiras, ascensores e planos inclinados, transpondo relevos e tecendo redes econômicas e sociais no território (SAMPAIO, 2011). Com a ampliação da área do Comércio, a ocupação inicial no sopé da falésia ganha uma vizinhança estruturada para atender à expansão do mercado capitalista europeu arranjado à produção agroindustrial da Bahia, (SANTOS, 2008) principalmente durante a segunda metade do século XIX, quando abrem-se ferrovias e aflui um grande número de migrantes para a cidade: expandindo-a, moldando, criando e revalorando territórios (antigos e novos). 


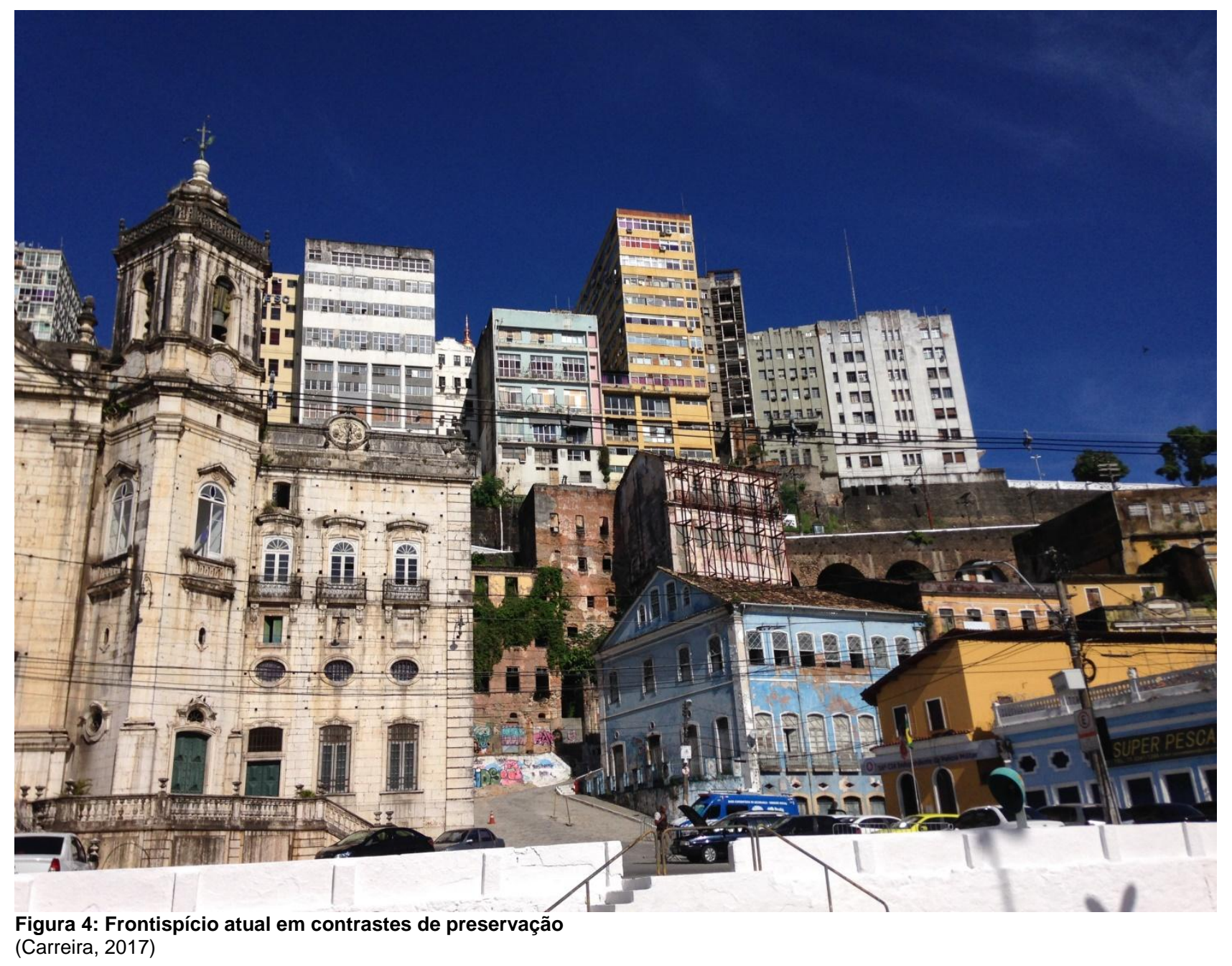

As décadas de 1960/1970 esgotaram a capacidade física do modelo econômico-financeiro do Comércio. Elas coincidem com a criação da Região Metropolitana de Salvador (RMS), pela implantação da Refinaria Landulpho Alves (RLAM) na década de 1950, do Centro Industrial de Aratu (CIA) nos anos 1960 e do Complexo Petroquímico de Camaçari (COPEC) em 1976, respectivamente localizados nos municípios vizinhos à Salvador, de São Francisco do Conde, Simões Filho e Camaçari.

O projeto industrial metropolitano, associado à decadência do setor primário, principalmente da região do Recôncavo baiano, resultou em forte processo de imigração rural/urbana e, por consequência, o significativo aumento da população urbana e transferência de concentração do capital financeiro para uma nova centralidade do território municipal, considerada mais adequada à expansão urbana. Ao final da década de 1970, o centro comercial-financeiro da cidade tinha migrado para uma nova região, onde se instalaram equipamentos estruturantes, como o Terminal Rodoviário Armando Viana de Castro e o primeiro shopping center da cidade - Shopping Iguatemi - que emprestou o nome ao bairro que se criava, a partir da lógica, conceitos e parâmetros do urbanismo moderno rodoviarista.

Esse processo provocou profundas alterações na dinâmica urbana de Salvador, sobretudo no Centro, que foi diretamente afetado com a transferência das principais atividades comerciais e de serviços para a nova centralidade. Além disso, a expansão urbana foi impulsionada para o vetor norte com a construção da Avenida Luís Viana Filho - conhecida como Avenida Paralela - e do Centro Administrativo da Bahia (CAB) no entorno desta avenida. Parte significativa do aparelho administrativo do Estado foi transferida para o $\mathrm{CAB}$, o que contribuiu para redimensionar e redirecionar os fluxos na cidade. Tais mudanças contribuíram para a implantação de loteamentos residenciais e a construção progressiva de equipamentos estruturantes, tais como o Centro de Convenções, o Parque de Exposições, centros de ensino médio e superior, ampliação do Aeroporto - que passa a ser classificado como internacional, outros shopping centers, hipermercados, entre outros. 
Na medida em que a cidade se expandiu, o Centro Histórico de Salvador (CHS) sofreu algumas alterações significativas, sobretudo em relação aos seus frequentadores e também moradores, logo, esta área perde importância no contexto urbano soteropolitano (PENA, 2013). De acordo com dados do Instituto Brasileiro de Geografia e Estatística (IBGE), entre os anos de 1970 e 2000 a cidade de Salvador teve um incremento de 1,4 milhões de habitantes, enquanto a área central da cidade perdeu 54 mil moradores. Em 2000 apenas 2,8\% (66,8 mil habitantes) da população soteropolitana (2,4 milhões de pessoas) residiam nos bairros do Centro Histórico e seu entorno (GOTTSCHALL E SANTANA, 2006 apud INFOCULTURA, 2008). Esses dados ilustram e explicam o esvaziamento sofrido pelo Centro, sobretudo pela perda de moradores das classes média e média-alta, que passaram a fixar-se nas áreas próximas ao Iguatemi. Ressalte-se que bairros inteiros se estabeleceram na cidade para abrigar principalmente trabalhadores vinculados aos setores modernos da economia que consolidava.

Contudo, essa ideia de esvaziamento é relativizada por Drummond (2012), que acredita que o Centro nunca deixou de ser um lugar frequentado. Para este autor, o que houve na segunda metade do século XX foi uma mudança no perfil de frequentadores do Centro, ou seja, deixaram de ir a esta área os "flâneurs provincianos" e a mesma passou a ser utilizada mais constantemente por pessoas de menor renda.

Após 400 anos, a primeira zona comercial de Salvador inicia seu processo de mudança do perfil socioeconômico e cultural da população residente e dos frequentadores, experimentando um acelerado processo de decadência, com transformações endêmicas de vulnerabilidade social, fragmentação da identidade urbana e dilapidação de seu conjunto arquitetônico.

\section{EXPERIÊNCIAS DE RECUPERAÇÃO DOS CENTROS URBANOS}

\subsection{Medellín, Colômbia}

Conforme Orrego (2012), as intervenções em centros urbanos nas últimas décadas têm sido realizadas tendo como modelo inspirador o modelo de Barcelona dos anos 1990, quando a cidade se preparou para as Olimpíadas. Este modelo foi amplamente difundido, sobretudo na América Latina. De modo geral, as intervenções visam recuperar as áreas centrais por meio do fomento ao turismo e ao consumo, ou seja, via desenvolvimento econômico. Segundo o autor, "este processo visa atrair grandes investimentos para a geração de projetos de grande porte: promoção de grandes equipamentos públicos e de lazer, a valorização de conjuntos históricos, criando espaços especializados para o consumo" (ORREGO, 2012: s.p.).

Nessa vertente, ou seja, no âmbito do planejamento estratégico, a cidade é considerada um produto a ser vendido em um mercado global altamente competitivo. Sendo assim, serão bem sucedidas aquelas cujo marketing urbano for capaz de construir uma imagem mais atrativa. Como explica Huyssen (2000: 100 apud BOTELHO, 2005: 56), "a imagem da cidade propriamente dita torna-se central para seu sucesso em um mundo globalmente competitivo".

Esse tipo de intervenção pode ser observado em diversas cidades brasileiras e outras latinoamericanas, como Salvador e Rio de Janeiro, no Brasil, e Medellín, na Colômbia. Em Salvador, as intervenções ocorridas a partir dos anos 1990 capitaneadas pelo Estado visavam a recuperação do Pelourinho, mas não para os habitantes da área e sim como um corredor cultural como simulacro de uma dinâmica desarticulada da dinâmica urbana da época. De área residencial, as principais ruas da área passaram a abrigar lojas de souvenires e outros atrativos para o setor turístico. Uma das mais delicadas consequências foi o processo de gentrificação, ou seja, de expulsão da população local para que o projeto fosse efetivado.

Segundo Orrego (2012), o Centro de Medellín sofreu profundas alterações a partir de 1970 devido a mudanças em seu contexto urbano, como a criação de novos polos industriais e o deslocamento do comércio, a implantação do shopping center e outros, levando a um esvaziamento da área. Alguns desses elementos assemelham-se aos aspectos observados em Salvador e outras cidades brasileiras, além de terem acontecido aproximadamente na mesma época. A saída escolhida pelo governo local de Medellín foi o planejamento estratégico como uma maneira de recuperar a área central.

O autor acrescenta que após a reforma constitucional na Colômbia em 1991, o governo colombiano instituiu na Lei no 388/1997, ${ }^{1}$ a obrigatoriedade da elaboração de Planos de Ordenamento Territorial (POT) pelos

\footnotetext{
Ver Lei no 388 de 1997 que disciplina sobre o planejamento urbano na Colômbia: <http://www.secretariasenado.gov.co/senado/basedoc/ley 0388 1997.html>.
} 
municípios com mais de 100 mil habitantes, como Medellín, fornecendo diretrizes para intervenções urbanas considerando aspectos sociais, econômicos e ambientais, e resultando em planos específicos para cada área onde estas deveriam ocorrer. Segundo a lei supracitada, o planejamento deve ser realizado com participação cidadã, democratizando a tomada de decisões na elaboração dos planos entre população e governo. Devendo vigorar durante três períodos de governo, os planos de ordenamento consistem em um conjunto de ações político-administrativas e instrumentos de gestão e planejamento fundamentais para a efetivação das intervenções urbanas.

O Plano de Medellín centrava-se na preservação do patrimônio edificado como elemento cultural para alavancar a área, o que aconteceu mediante parceria entre a prefeitura e a iniciativa privada. Orrego (2012) acrescenta que, por um lado, esse processo tentou recuperar uma importante área da cidade, apesar das dificuldades sociais, políticas e econômicas.

A prefeitura local empreendeu esforços para erradicar a violência por meio da educação, tendo sido remodeladas e construídas escolas e parques-bibliotecas. Isto refletiu em slogans da cidade, como "Medellín, la más educada" e "El centro vive". Contudo, segundo Orrego (2012), a intervenção desconsiderou parte do patrimônio edificado na busca por construir uma nova imagem para Medellín. O autor chamou isto de "duplo processo de tombamento", uma vez que houve a intenção de preservar uma parte da área histórica, mas que por outro lado, resultou na destruição de lugares considerados importantes patrimônios arquitetônicos da cidade, quais sejam: a Praça de Cisneros e a passagem Sucre. Apesar disto, as ações são consideradas bem sucedidas, de modo que o conjunto de intervenções realizadas (não apenas na área central) ficou conhecido como "modelo Medellín", tendo sido premiado em 2013 pelo Urban Land Institute como a mais inovadora do mundo, além de ter adquirido uma projeção mundial, dadas as profundas mudanças sociais e urbanas alcançadas (GHIONE, 2014).

\subsection{Montreal, Canadá}

Até 2002 o patrimônio de Montreal experimentava um processo de franca decadência, quando se inicia a elaboração de um plano, Le Sommet de Montréal (MONTREAL, s.d.), que abrigava diversos projetos de políticas setoriais, estratégicas e de ordenamento do território urbano, dentre elas a Política do Patrimônio. ${ }^{2}$ Foram então gerados documentos específicos ligados à preservação do patrimônio construído e paisagístico, natural, arqueológico, social, cultural, material e imaterial e das tradições comemorativas, estabelecidos em diretrizes por um termo de compromisso (de direitos e responsabilidades) para salvaguarda daquele conjunto.

As intervenções foram asseguradas por um arcabouço legislativo aplicado à realidade local, diante das políticas preconizadas no Sommet de Montreal, tendo sido sancionadas as seguintes leis:

- Lei sobre os bens culturais: permite ao governo e aos municípios da província do Quebec de atribuir o status de proteção a bens e territórios patrimoniais, submetendo os proprietários a medidas de controle;

- Lei de planejamento urbano: obriga as cidades a elaborar planos diretores urbanos e a respectiva legislação urbanística, prescrevendo elementos obrigatórios e facultativos. Permite ainda ao setor público intervir em obras que possam impactar o patrimônio e estabelece grandes linhas do processo participação popular e audiências públicas e dos conselhos municipais de urbanismo;

- Lei do Código de Obras e outras regulamentações relacionadas: permite o controle da qualidade das obras de construção e reforma, para que não causem riscos à conservação e valorização do patrimônio;

- Lei de qualidade do ambiente construído e regulamentações relacionadas: patrimônio construído, arqueológico e entorno natural, como os rios;

- Lei de conservação do patrimônio natural: tem por objetivo salvaguardar as características, a diversidade e a integridade do patrimônio natural de Quebec com medidas de proteção da diversidade biológica e dos componentes dos ecossistemas;

- Lei de sepultamentos e exumações: prevê procedimentos específicos, em respeito às antigas sepulturas e apoio a investigações arqueológicas;

- Lei de arquivamentos: estabelece que o município adote uma política de gestão e salvaguarda de documentos patrimoniais, ativos e inativos, e instituir procedimentos e um calendário de utilização e suportes de conservação.

\footnotetext{
${ }^{2}$ Contextualizado em 6 temas básicos: metrópole inovadora e criativa, do saber e da cultura, da democracia, igualdade e transparência, do desenvolvimento permanente, da solidariedade e qualidade de vida, através de uma gestão efetiva a serviço da de seus cidadãos.
} 
O Sommet de Montreal demonstra uma forte decisão política dos gestores públicos, agentes sociais e população pela preservação e conservação de seu patrimônio material, imaterial e natural. Este plano se consolida pela criação de um arcabouço legal tão significativo quanto integrado, traduzindo uma excepcional percepção de planejamento feito a partir de um processo endógeno.

Quinze anos depois, essa iniciativa vem apresentando resultados que não deixam de ser estratégicos, mas que se apresentam por sua sólida e perene identidade para as atuais e futuras gerações.

Nas palavras do então prefeito de Montreal, Gérald Tremblay, "la qualité de vie, la convivialité, et l'attrait de Montréal sont, en grande partie, tributaires de son patrimoine, lequel participe à la définition de ce que nous sommes et permet de nous projeter avec confiance dans l'avenir. Plus qu'une valeur ajoutée, le patrimoine represente un véritable facteur de développement culturel, social et économique." (MONTREAL, s.d.).

Pode-se inferir que se trata de um plano estratégico fundado na história, na cultura, no pertencimento e confiança de uma sociedade que se fundou, reconhece e mantém a solidez da identidade que lhe é própria peculiar e firme nos seus valores e convicções.

\subsection{Tentativas de recuperação do Centro Antigo de Salvador}

Atualmente, o Centro Antigo de Salvador corresponde ao grupamento de bairros que se formaram a partir das freguesias de Salvador, desde fundação até a metade do século XX, localizados nas duas cidades - alta baixa. (NASCIMENTO, 2007).

O patrimônio arquitetônico, arqueológico, paisagístico e natural da região do Comércio é rico e revela marcas de diferentes épocas. Isto exige uma gestão complexa que proporcione a compreensão e contemplação desses bens que atestam a evolução das funções que aquela parte da cidade adquiriu no tempo e o perfil da coletividade que a frequentou e frequenta.

Apesar da força conferida pelo conjunto patrimonial (material e imaterial), impressiona o estado de degradação em que se encontra o Comércio. É preocupante a situação de muitos imóveis pelo estado de degradação avançada: alguns desabaram e outros tantos prestes a ruir, estão escorados - um cenário que lembra uma cidade em guerra. Muitos edifícios são coabitados por famílias que não têm moradia, outros tantos estão ocupados por jovens e adultos viciados principalmente no crack. A perda do status de centro econômico e financeiro há cerca de 40 anos, sem ações efetivas de reabilitação, não só coloca em risco a memória da cidade como retrata um descaso de proporções inadmissíveis. 


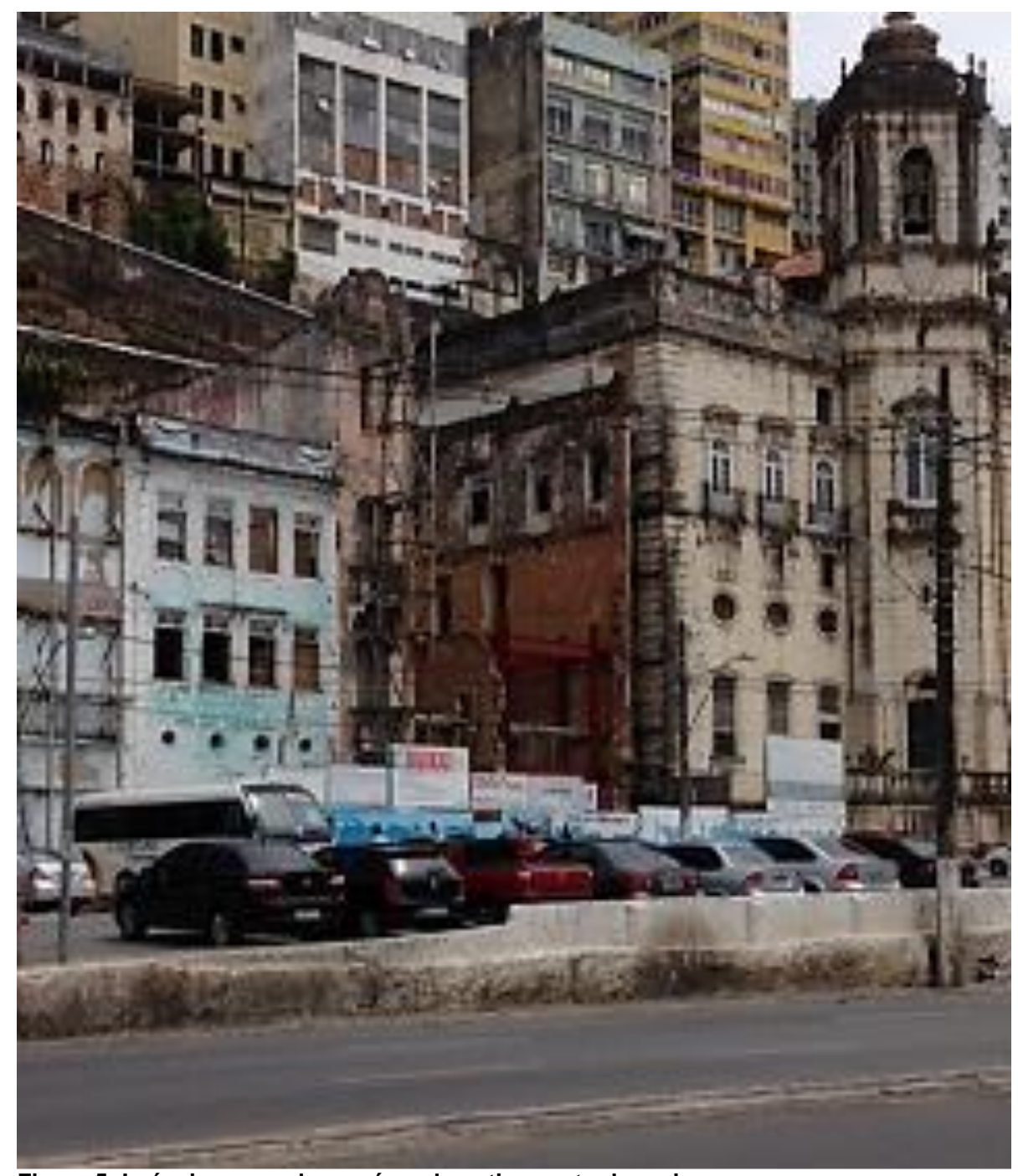

Figura 5: Imóveis escorados na área do antigo porto da praia

(Carreira, 2016)

Em vários momentos, as administrações municipal e estadual têm elaborado diagnósticos, prognósticos, diretrizes e programas para a recuperação e revitalização do patrimônio arquitetônico que representa a memória da cidade, porém sem resultados significativos.

Segundo Bomfim (2010), algumas cidades do mundo, como Grenoble e Le Puy na França, Urbino Brescia, Ferrara e Bolonha na Itália e Salamanca na Espanha, adotaram sistemas diferenciados para a revitalização dos seus respectivos centros de origem.

Entendendo o centro antigo como espaço a preservar, percebe-se que a adoção de legislações específicas a exemplo do tombamento da área - pode levar a um processo de segregação, na medida em que o espaço e a região não sejam vistos como parte da cidade, portanto não inseridos e conectados com a dinâmica de desenvolvimento urbano. Assim, o que assistimos em Salvador são inciativas governamentais que pretendem a revitalização do Centro Antigo sem que este seja entendido como mais um território urbano, com as necessidades inerentes aos seus moradores e frequentadores, como comércio, serviços, infraestrutura, não deixando de salientar a possibilidade de desenvolver ações estratégicas que valorizem o seu patrimônio cultural material e imaterial, possibilitando um desenvolvimento sustentável, preconizado na legislação urbanística.

Vários planos, programas e projetos foram elaborados e alguns implantados no Centro Antigo. Entretanto, os resultados foram pouco exitosos na medida em que as intervenções contemplavam parcialmente a problemática do seu conjunto, não proporcionando a recuperação, reabilitação e revitalização integrada e eficaz, como os abaixo citados: 
Em 1959 o Instituto Histórico e Artístico de Salvador (IPHAN) realizou obras no Centro Histórico, restritas aos monumentos religiosos de excepcional valor cultural através do Programa de Preservação do Centro Histórico de Salvador.

- O Instituto do Patrimônio Artístico e Cultural da Bahia (IPAC), criado em 1967, tinha como meta revitalizar o tecido urbano, envolvendo a restauração dos imóveis e a preservação social. A partir da década de 1970 desenvolveu vários estudos, levantamentos sócio-demográficos, programas e projetos no intuito de reabilitar o patrimônio histórico. Porém, poucos foram os que saíram da prancheta e alguns imóveis objetos de intervenções foram utilizados como sede de órgãos públicos (BOMFIM, 2010).

- Em 1978, estudos foram desenvolvidos objetivando melhorar a mobilidade no Centro Histórico, priorizando o transporte público e o pedestre.

- O projeto Centro Administrativo Municipal Integrado (CAMI), desenvolvido pela Prefeitura de Salvador, visava revitalizar alguns imóveis e trazer de volta para o Centro Antigo alguns dos órgãos municipais que tinham sido transferidos para outras localidades. No entanto, a tentativa de fortalecer o centro cívico da cidade não alcançou os objetivos estabelecidos.

Entre 1981 e 1982 o IPAC realizou em Salvador uma tentativa de aplicação de recursos do Banco Nacional de Habitação $(\mathrm{BNH})$, através da dos órgãos responsáveis (URBIS/CONDER), para a recuperação de 85 imóveis do patrimônio habitacional do Centro Histórico, com a elaboração de projetos arquitetônicos e contatos com famílias - possíveis mutuários - para a aquisição de unidades habitacionais decorrentes da adaptação de sobrados arruinados.

Tratava-se de uma experiência nova - tanto para o BNH quanto para o IPHAN e Fundação Pró-Memória - a tentativa de compatibilizar a demanda de recursos do patrimônio histórico com a oferta do Sistema Financeiro de Habitação. (BOMFIM 2010: 214).

Constatou-se a inadequação dos mecanismos técnicos e financeiros do BNH com os projetos propostos.

- Em 1983 foi criado o Escritório Técnico de Licença e Fiscalização (ETELF), composto por representantes das instâncias municipal, estadual e federal, objetivando o licenciamento e fiscalização de projetos no Centro Histórico. As ações não causaram impactos significativos.

- $\quad$ Em 1985, a Organização das Nações Unidas para Educação Ciência e Cultura (UNESCO) declara Salvador Patrimônio da Humanidade e tomba a área situada entre Santo Antônio Além do Carmo e o Sodré.

- $\quad$ Por iniciativa do governo municipal foi criado em 1986 o Parque Histórico do Pelourinho, abrangendo uma área de 31 hectares. Mais uma vez estudos e projetos pontuais foram elaborados, porém a implantação de alguns deles não trouxe mudanças significativas para a área;

- Nos anos 1980, a sede da Prefeitura Municipal de Salvador, que tinha sido remanejada para o bairro de Brotas, voltou a se instalar no Centro Antigo como um ato simbólico de valorização e fortalecimento do centro cívico municipal. Apesar das várias tentativas de atrair investimentos nas esferas nacional e internacional, privadas e públicas, a experiência não obteve o êxito necessário à revitalização da área. Não havia na época, instrumentos leais que garantissem e/ou incentivassem tais parcerias com o setor privado, bem como um Plano Diretor que visasse a sustentabilidade da área.

Este intento de consolidação de um "parque construído", de caráter urbano, composto por edificações e logradouros públicos de caráter urbano, teve vida curta. Na gestão do prefeito Fernando José (1989-1992), a administração do Parque Histórico do Pelourinho foi transformada na primeira Administração Regional da municipalidade, a AR - Centro, que ampliou os limites de sua ação para o centro de Salvador e mais 36 bairros do seu entorno.

Aparece aí um considerável fator negativo a se levar em conta a administração pública brasileira: a descontinuidade administrativa. A alternância de governos, 
salutar para a democracia, no mais das vezes resulta em paralisações de importantes programas em desenvolvimento, particularmente quando ocorre mudança políticopartidária de gestores urbanos (BOMFIM, 2010: 227).

- A partir de 1992 o Governo do Estado da Bahia empreendeu o Programa de Recuperação do Centro Histórico de Salvador (1992-2010) com três estratégias: investimento no turismo com fins de desenvolvimento econômico, valorização da identidade cultural e das tradições baianas e a manutenção de um grupo político e econômico no estado. De acordo com Mourad (2011) as ações do poder público no âmbito desse programa provocaram a retirada da população pobre da área, em claro processo de gentrificação e evidentes benefícios ao capital privado.

Constata-se que as diversas tentativas elaboradas não tiveram termo devido a fatores técnicos, políticos, financeiros, entre outros como instrumentos legais capazes de entender a problemática da área na sua totalidade e possibilitassem que o Centro Antigo, apesar da criação e expansão de novos centros e subcentros, se sustentasse com qualidade urbanística arquitetônica.

Em 2007 foi criado pelo Governo do Estado da Bahia, o Escritório de Referência do Centro Histórico de Salvador (ERCAS), enquanto unidade gerencial da Secretaria de Cultura do Estado (SECULT) que coordenou a elaboração do Plano de Reabilitação Participativo do Centro Antigo de Salvador, sendo também responsável pela articulação entre os três entes federativos (União, Estado e Município) e com a sociedade civil.

Em dois anos e meio, o planejamento para requalificação da área foi desenvolvido com a participação de mais de 600 representantes de entidades locais, tendo sido realizados quatro encontros das câmaras temáticas e um Workshop Internacional. Saliente-se a importância da obrigatoriedade da adoção de instrumentos de gestão democrática, definidos desde 2001 pela urbana nacional, como o amplo processo participativo dos atores sociais locais.

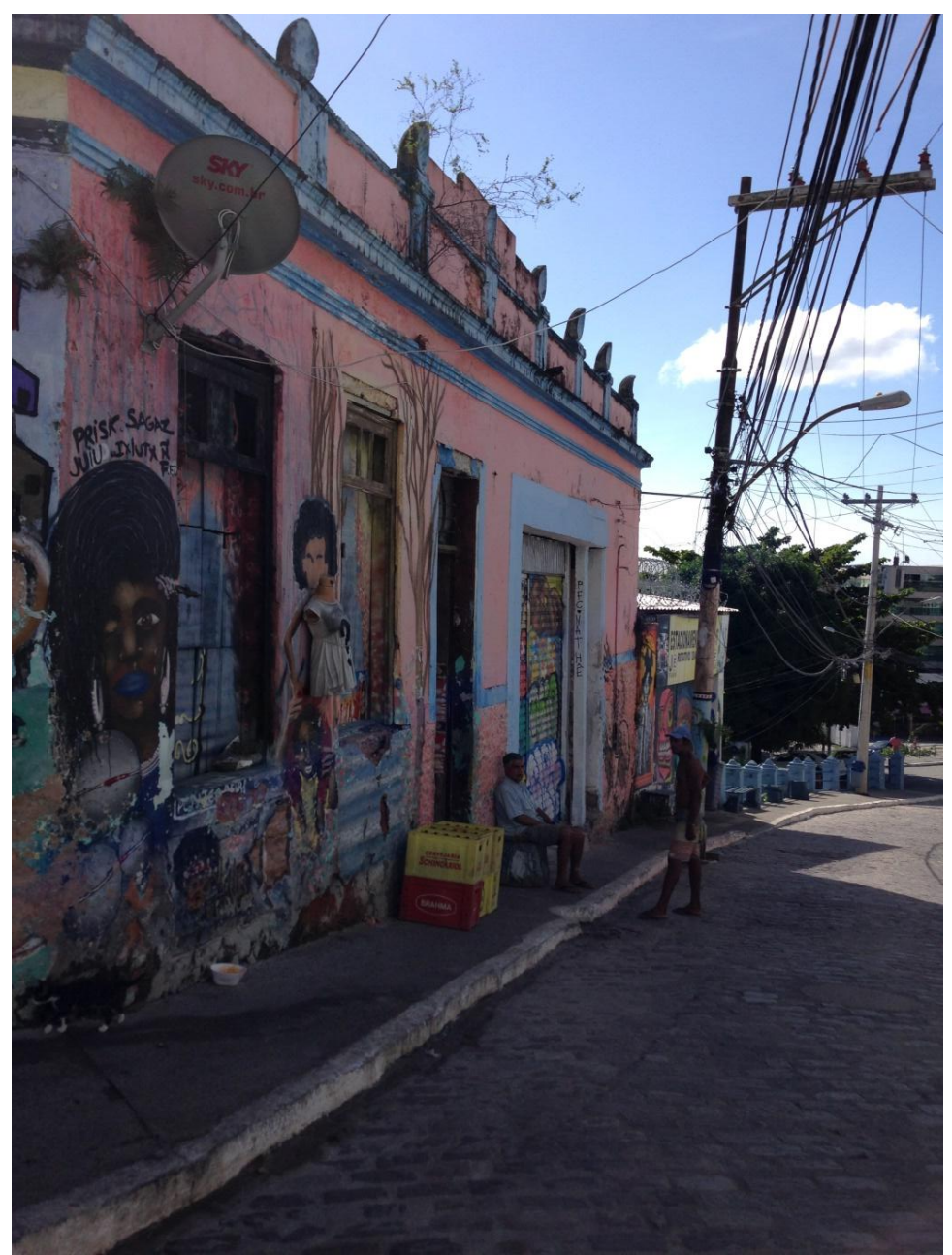

Figura 6: Moradores da área do Comércio (Carreira, 2017) 
O Plano de Reabilitação indica a necessidade de desenvolver um sistema de informações para a avaliação e monitoramento de cada conjunto de ações nos seguintes aspectos: social, econômico, urbanístico, dentre outros, auferindo resultados quantitativos e qualitativos. O sistema em questão propõe a adoção de indicadores que permitam adequações durante o processo, através de avaliação (interna e externa). $O$ relatório gerencial busca, portanto, iniciar o processo de avaliação e monitoramento do Plano de Reabilitação Participativo do Centro Antigo de Salvador. Apresenta, ainda, diagnósticos sobre aspectos econômicos, turísticos, habitacionais, acessibilidade, ocupação urbana, segurança pública, vulnerabilidade social e meio ambiente urbano.

\subsubsection{Ações recentes no Centro Antigo de Salvador}

Recentemente, em dezembro de 2016, a Prefeitura de Salvador sujeitou à Câmara Municipal o Projeto de Lei no 302/2016, propondo o estabelecimento do Programa de Incentivo à Restauração e Recuperação de Imóveis do Centro Antigo de Salvador - Programa Revitalizar.

Voltado aos 11 bairros que integram o centro antigo da cidade, o programa tem por objetivo a recuperação e utilização de casarões em ruínas, deteriorados ou vazios da região. A iniciativa que tem gestão da Secretaria Municipal de Cultura (SECULT), propõe a redução ou isenção de impostos municipais para que o proprietário seja incentivado a reformar, restaurar e uso ao imóvel. Através de incentivos, o programa pretende alcançar mais de uma centena de edifícios históricos, cuja situação de risco vem sendo mapeada.

Segundo os gestores municipais, a proposta se configura como uma ação embrionária de estímulo ao restauro e utilização dos imóveis (em fase de levantamento) que, se não atendida no prazo de cinco anos após a notificação e oferta de incentivos, possibilita ao setor público penalizar o proprietário por desapropriação do bem.

Apesar de não estar claro, o discurso pressupõe um entendimento bastante amigável com duração de cinco anos, a partir de quando poderão ser aplicados instrumentos do Estatuto da Cidade - mencionado no documento redigido pelo prefeito ao presidente da Câmara de Vereadores.

De forma inovadora em nosso Município, estamos propondo, ainda, a aplicação, na área do Centro Antigo, como já previsto no novo PDDU, de instrumento jurídico específico, trazido ao ordenamento jurídico do país pelo Estatuto da Cidade (Lei №. 10.527, de 10 de julho de 2001), qual seja o da edificação ou utilização compulsória, para aplicação no caso daqueles proprietários que, mesmo ante a política de incentivos aqui estabelecida, persistam, de forma renitente, em manter não edificado, não utilizado ou subutilizado o seu imóvel. Esse constitui, aliás, um instrumento de fundamental importância para evitar que voltem a acontecer desmoronamentos, repito, inclusive de imóveis tombados, na área de todo o Centro Antigo, induzindo, por outro lado, a plena utilização da infraestrutura e serviços públicos aí disponíveis. Finalmente, nossa expectativa é de que, ao final dos próximos 10 anos, todo o Centro Antigo esteja inteiramente recuperado e revitalizado. Trata-se do centro tradicional da Cidade, onde se concentra parte significativa da vida urbana, que se pretende qualificar e valorizar ainda mais. ${ }^{3}$

A partir do texto supracitado, trazemos as indagações: configura um programa vago e esvaziado de intenções efetivas, mas que, por outro lado, é leniente e beneficia o setor imobiliário. O referido Projeto de Lei elenca uma série de benefícios e incentivos fiscais: sobre a aquisição de imóveis, sobre a propriedade predial e territorial urbana, sobre a execução de obras e sobre serviços, os quais certamente não contemplam a população de baixa renda residente no Centro Antigo, mas são muito caros ao mercado imobiliário altamente interessado na área.

\footnotetext{
3 Ver mensagem do prefeito Antonio Carlos Peixoto de Magalhães Neto ao presidente da Câmara de Vereadores: <http://www.cms.ba.gov.br/upload/Mens._20_PLE_302_20161216105745406902.pdf>.
} 


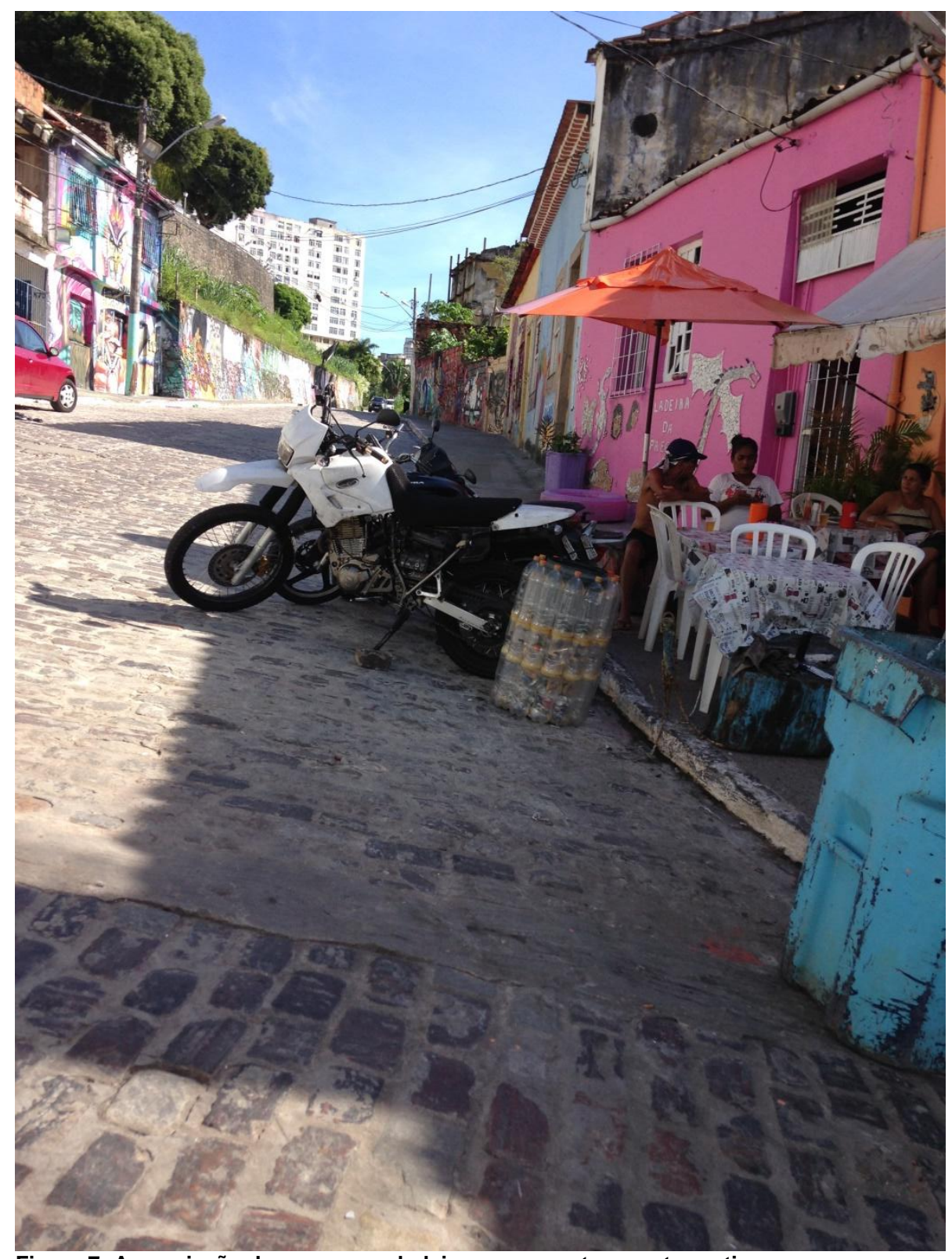

Figura 7: Apropriação de espaço em ladeira que conecta o centro antigo (Carreira, 2017)

Com horizonte temporal de 10 anos, o gestor municipal pretende que "todo o Centro Antigo esteja inteiramente recuperado e revitalizado. Trata-se do centro tradicional da Cidade, onde se concentra parte significativa da vida urbana, que se pretende qualificar e valorizar ainda mais." " Apesar do Projeto de Lei mencionar a questão residencial, não há indicação de como pode ser viabilizada a reforma de habitações cujos moradores não tenham condições financeiras de fazê-lo e possam permanecer em seu lócus. A proposta deixa clara a intenção de valorizar e aumentar a competitividade turística da região, numa típica utilização da cultura como base de intervenções urbanas no âmbito do planejamento estratégico.

A minuta da lei não referencia os moradores em situação de rua que vagam e se instalam ao abrigo de prédios insalubres com risco de desabamentos, fato corrente no bairro do Comércio. A população residente critica severamente o projeto e denuncia a falta de participação cidadã na elaboração do programa, bem como a falta de garantias de permanência dos atuais moradores. As críticas iniciam-se pelo próprio nome do programa, pois "não se revitaliza um lugar onde há vidas". ${ }^{5}$

4 Ver mensagem do prefeito Antonio Carlos Peixoto de Magalhães Neto ao presidente da Câmara de Vereadores:
<http://www.cms.ba.gov.br/upload/Mens._20_PLE_302_20161216105745406902.pdf>.
${ }_{5}$ Ver "Moradores do Centro Histórico protestam contra 'Programa Revitalizar' na Câmara": Ver "Moradores do Centro Histórico protestam contra 'Programa Revitalizar' na
<http://www.bahianoticias.com.br/noticia/206376-moradores-do-centro-historico-protestam-contra-programa-revitalizar-nacamara.html>. 


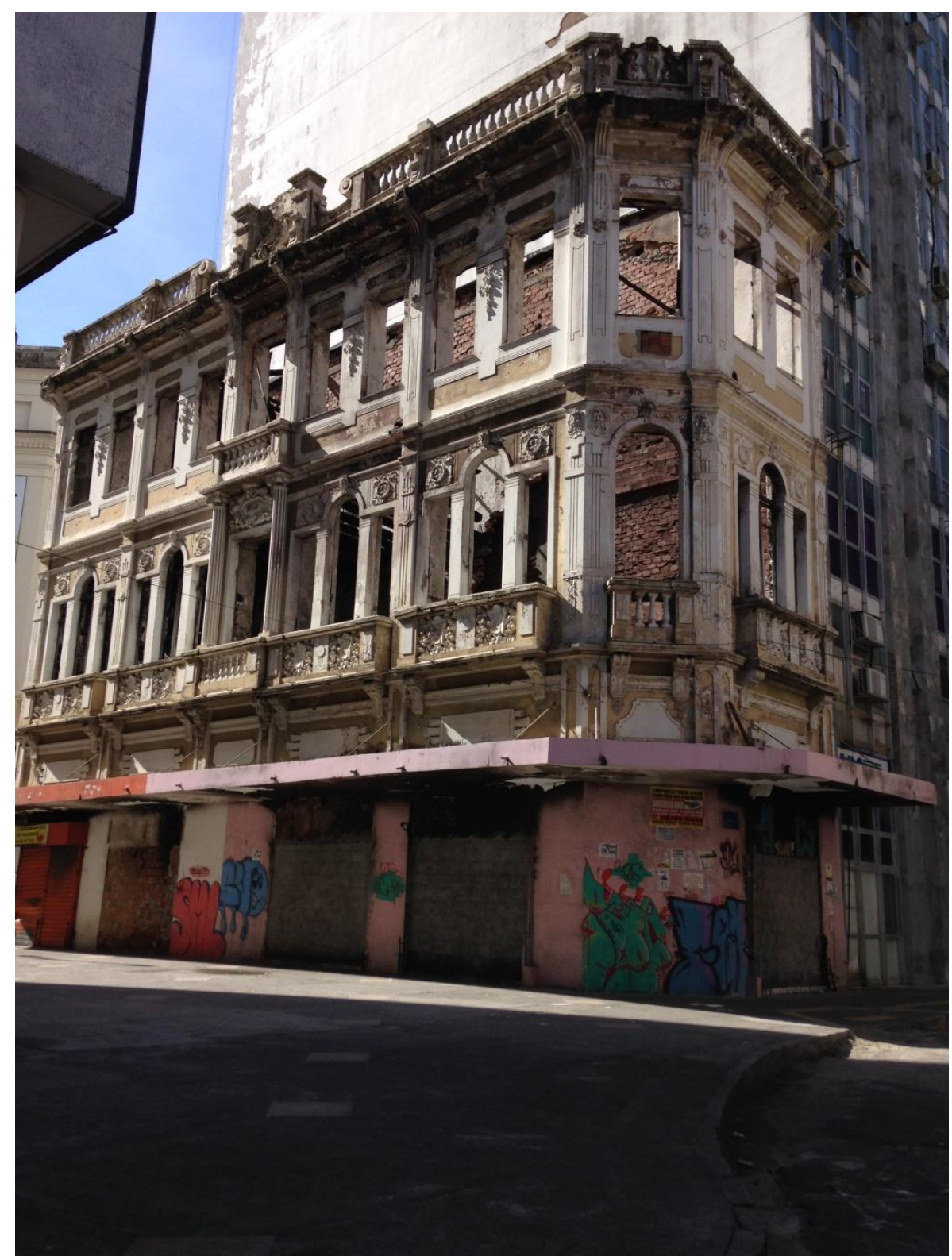

Figura 8: Marcas temporais em imóvel do Comércio (Carreira, 2017)

Vale ressaltar que, para além das ações empreendidas pelo poder público na área, há um crescente interesse do capital turístico e imobiliário no Centro Histórico e entorno, dada a sua localização privilegiada, importância cultural, seu patrimônio edificado e a consequente valoração no contexto soteropolitano. Como fora noticiado em 2015, apenas uma empresa, a Fera Empreendimentos, adquiriu cerca de 120 imóveis nos arredores da Rua Chile, considerada a mais antiga do Brasil, além de ter reformado e inaugurado recentemente o luxuoso Fera Palace Hotel na mesma rua (WIZIACK, 2015). Na matéria jornalística, percebe-se que a intenção é transformar a área em complexo turístico, pondo em xeque a população ainda residente na área e revelando o tipo de "revitalização" que se pretende para esse espaço, que notadamente não coaduna com a pauta do direito à cidade.

\section{CONSIDERAÇÕES FINAIS}

Observa-se que as políticas elaboradas para o centro de Medellín consideraram a população afetada, incorporando variadas ações de cunho social, com especial destaque aos programas voltados à educação. O que pressupõe ser essa uma área de funções variadas, com uma população residente que demanda por equipamentos e serviços sociais, além de se observar que as políticas locais incluíram o centro antigo no bojo dos demais projetos de revitalização para diversas áreas da cidade. Assim, o centro de Medellín não foi 
tratado apenas como uma área histórico-cultural, voltada ao desenvolvimento turístico, mas como uma área urbana de forte identidade, cujos habitantes têm a oferta de bens sociais e também a possibilidade de desenvolver atividades econômicas, entre elas as voltadas ao turismo.

Já em Montreal, o fato do entorno ser considerado no processo de revitalização do centro antigo demonstra capilaridade e integração com a cidade de maneira geral. Vale ressaltar o processo participativo e democrático, que resulta no atendimento das necessidades locais da população permanente, garantindo a vitalidade e integração com o processo de desenvolvimento urbano como um todo.

No Plano Salvador 500, a legislação urbanística federal que garante o Direito à Cidade passa ao largo de políticas e da aplicação de instrumentos efetivos de recuperação das áreas antigas e de inserção social provida de condições ambientais, econômicas, sociais e culturais com a mobilização, engajamento e participação da sociedade. Apesar das significativas tradições culturais locais que fortalecem a identidade da cidade - por que não dizer do Brasil - as ações e projetos para a área desconsideram suas riquezas imateriais, as necessidades básicas da maioria da população residente e a função social do solo urbano.

Apesar dos exemplos de cidades e mecanismos legais apresentados neste artigo, Salvador, primeira cidade fundada no Brasil colonial, continua submetida a tentativas de revitalização e recuperação do seu conjunto patrimonial, sendo claramente perceptível a fragilidade das proposições que, efetivamente, se devem e se servem de apoio do mercado imobiliário. É notório o interesse do poder público em promover a área para fins de desenvolvimento turístico e econômico, desconsiderando a maioria da população residente, de baixa renda, acirrando ainda mais as desigualdades socioespaciais existentes na cidade.

Concluímos que, dadas as suas particularidades, o Centro Antigo de Salvador requer planos e ações inclusivas e integradas, elaboradas em processo participativo de planejamento com maior envolvimento de diversos atores sociais, sobretudo aqueles que representam a identidade local, ou seja, os moradores da área, e apresentam carências e demandas a suprir. Como em Salvador esta não tem sido a inclinação do poder público, é ainda mais importante e urgente que a população reivindique com maior intensidade o cumprimento efetivo dos princípios preconizados na Constituição Federal e no Estatuto da Cidade, que os cidadãos exijam e façam-se presentes nos distintos lugares de disputa do espaço urbano, para que o Direito à Cidade não seja mera utopia e se reflita em ações concretas que beneficiem a coletividade na dinâmica urbana.

\section{REFERÊNCIAS}

BOMFIM, J. D. (2010). O centro Antigo da Cidade do Salvador: sua integração sociourbana. Feira de Santana: UEFS Editora.

BOTELHO, Tarcísio R. (2005). Revitalização de centros urbanos no Brasil: uma análise comparativa das experiências de Vitória, Fortaleza e São Luís. Revista Eure (Santiago de Chile), Vol. XXXI, № 93, pp. 5371, Santiago de Chile. Disponível em: <http://www.scielo.cl/pdf/eure/v31n93/art04.pdf>. (Consulta: 10/01/2017).

DRUMMOND, W. L. L. (2012). Do Centro Histórico Expandido: fantasmagorias \& infames. Cadernos PPGAU/FAUFBA (Salvador) ano 10, n. 2, 85-96.

Estatuto da Cidade (2001), aprovado pela Lei oㅜ 10.257/2001, de 10 de julho de 2001.

GHIONE, R. (2014). Transformação social e urbanística de Medellín. Minha Cidade (São Paulo), ano 14, n. 166.07, Vitruvius. Disponível em: < http://www.vitruvius.com.br/revistas/read/minhacidade/14.166/5177>. (Consulta: 12/02/2017).

LEFEBVRE, H. (1978). El derecho de La ciudad. Barcelona: Edicions 62 S/A.

HARVEY, D.(2012). O direito à cidade. Lutas Sociais (São Paulo), n. 29, 73-89. Disponível em: <http://www4.pucsp.br/neils/downloads/neils-revista-29-port/david-harvey.pdf>. (Consulta: 20/04/2017).

INFOCULTURA - Centro Antigo de Salvador: uma região em debate. (2008) V.1, n.2. Salvador: Secretaria de Cultura do Estado, Fundação Pedro Calmon Centro de Memória e Arquivo Público da Bahia.

Lei de Ordenamento do Uso e Ocupação do solo de Salvador, aprovada pela Lei n 9.148/2016.

Lei 388 de 1997, aprovada pelo Congresso da Colômbia em julho de 1997. Disponível em: <http://www.secretariasenado.gov.co/senado/basedoc/ley_0388_1997.html>. (Consulta: 20/04/2017).

Estatuto da Cidade (2001), instituído pela Lei no 10.257, de 10 de julho de 2001. Disponível em: <http://www.planalto.gov.br/ccivil_03/leis/LEIS_2001/L10257.htm>. (Consulta: 13/01/2017).

MONTREAL, Prefeitura de Montreal. (s.d.). Projet de politique du patrimoine. Montreal: Mairie de Montréal. 
MOURAD, L. N. (2011). O processo de gentrificação do Centro Antigo de Salvador 2000 a 2010. Tese (Doutorado em Arquitetura e Urbanismo) - Faculdade de Arquitetura e Urbanismo. Universidade Federal da Bahia.

NASCIMENTO, A. A. V. (2007). Dez freguesias da cidade do Salvador: aspectos sociais e urbanos do século $X I X$. Salvador, EDUFBA.

ORREGO, J. F. M. (2012). Práticas contemporâneas no centro urbano: o caso da revitalização urbana na área de Cisneros, Medellín-Colômbia. III Seminário Internacional Urbicentros, 2012, Salvador. Anais... Salvador: PPGAU/UFBA. Disponível em: <http://www.ppgau.ufba.br/urbicentros/2012/ST219.pdf>. (Consulta: 25/01/2017).

PENA, J. S. (2013). Espaços de excitação: cines pornôs no Centro de Salvador. Dissertação (Mestrado em Arquitetura e Urbanismo) - Faculdade de Arquitetura e Urbanismo. Universidade Federal da Bahia. Disponível em: <https://repositorio.ufba.br/ri/handle/ri/19329>. (Consulta: 13/04/2017).

Plano Diretor de Desenvolvimento Urbano de Salvador (2016), aprovado pela Lei $n^{\circ}$ 9069/2016. Disponível em: $\quad$ <http://www.sucom.ba.gov.br/wp-content/uploads/2016/07/LEl-n.-9.069-PDDU-2016.pdf>. (Consulta: 15/01/2017).

Plano Salvador 500. Disponível em:<http://www.plano500.salvador.ba.gov.br>. (Consulta: 13/01/2017).

Projeto de Lei $\mathrm{n}^{\circ}$ 302/2016. Disponível em: <http://www.cms.ba.gov.br/upload/Mens._20_PLE_302_20161216105745406902.pdf>. （Consulta: 13/04/2017).

SANTOS, M. (2008). O Centro da cidade do Salvador: um estudo de Geografia Urbana. 2.ed. São Paulo: EDUSP; Salvador: EDUFBA.

SAMPAIO, C. N. (2005). 50 anos de urbanização: Salvador da Bahia no Século XIX. Rio de Janeiro: Versal.

TEIXEIRA, M. C. (2012). A forma da cidade de origem portuguesa. São Paulo: Editora Unesp: Imprensa Oficial do Estado de São Paulo.

VASCONCELOS, P. de A. (2002). Salvador: Transformações e Permanências (1549-1999). llhéus: Editus.

WIZIACK, J. (2015). Via mais antiga do país, em Salvador, será revitalizada para virar complexo turístico. Folha de São Paulo, 28/06/2015. Disponível $\quad$ em: <http://www1.folha.uol.com.br/mercado/2015/06/1648531-grupo-compra-123-imoveis-e-pretenderevitalizar-o-centro-historico-de-salvador.shtml>. (Consulta: 28/04/2017).

Fontes eletrônicas

http://www.bahianoticias.com.br/noticia/206376-moradores-do-centro-historico-protestam-contra-programarevitalizar-na-camara.html>. (Consulta: 30/04/2017). 